JANA MIKULOVÁ

Masaryk University, Brno

jmikulova@gmail.com

\title{
DIRECT SPEECH AND DIVERSITY OF VOICES IN SELECTED LETTERS OF CICERO TO ATTICUS II (INDIRECT SPEECH, MIXED QUOTATIONS AND COMPARISON WITH DIRECT SPEECH)
}

Keywords: direct speech, Cicero, Latin, reported speech, quotation

\begin{abstract}
This paper examines Cicero's use and introduction of direct speech in nine selected letters to Atticus. It shows that despite the informal traits found in the letters, Cicero is not innovative in his choice of means to introduce direct speech. The paper also notes transitional zones on the margin of the domain of direct speech and the interplay of intervening voices. In this way, it contributes to improving the knowledge of direct speech in classical Latin, which is a necessary starting point for research into its development. The analysis is divided into two parts. This part is aimed at the examination of indirect speech, mixed quotations and the interplay between different voices present in the selected letters.
\end{abstract}

\section{Introduction ${ }^{1}$}

In the article Direct speech and diversity of voices in selected letters of Cicero to Atticus I (direct speech), the use and introduction of direct speech in nine selected letters to Atticus ${ }^{2}$ was examined. It was shown that direct speech is introduced regularly by the verb inquam even in quite long dialogical passages and is almost never replaced by synonyms. This part will focus on indirect speech, mixed quotations and transitional zones on the margin of the domain of direct speech.

This paper was supported by Czech Science Foundation (project no. GA18-01878S, Introduction of Direct Speech in Latin).

2 Cic. Att. 2, 12; 5, 21; 6, 2; 7, 9; 7, 11; 8, 5; 9, 18; 13, 38; 13, 42. 


\section{Indirect speech}

If the use of direct speech is compared with the use of indirect speech after the same type of introducers (i.e. verbs of speech, nouns, pronouns, and zero marking), it can be seen that in the examined letters indirect speech is used more often (in 73 instances $^{3}$ ) than direct speech is. Indirect speech is marked by several well-known traits, such as the change of mood to infinitive or subjunctive, the change of person to the third person, the change of pronouns, and adverbials. ${ }^{4}$

The borderline of indirect speech may be fuzzy, particularly in relation to the types of reported speech that combine traits of indirect speech with those of direct speech (e.g. free indirect speech and other non-direct types of reporting). Rosén (2013: 255) claims that the classification of an utterance as free indirect speech cannot be based only on one feature deviating from prototypical direct or indirect speech but must be based on the set of such characteristics. In the letters examined here, instances of free indirect speech do not occur, although they do elsewhere in Cicero's correspondence. ${ }^{5}$

Turning to indirect speech in the selected texts, unsurprisingly most reported clauses are in the declarative ( 42 instances, accusative with infinitive (AcI)), followed by the imperative ( 26 instances, $u t$ clause or AcI) and the interrogative ( 5 instances) sentences. The reporting verb or noun precedes indirect speech in 51 instances, follows it in 15, and is found in mid-position in 5. Thus, indirect speech shows a clear preference for the ante-position and direct speech for the mid-position, although this latter is due to the frequent use of inquam. Disregarding inquam, both direct and indirect speech show a preference for the ante-position. Because of the small number of texts, it is not possible to draw any firm conclusions, but this finding could be an indication of a need for further research, particularly with regards to development in late Latin (see Gayno 2015; Mikulová 2015; Sznajder 2015). As regards introducing verbs and nouns, indirect speech shows significantly higher variability in verbs of speech than direct speech does. The most frequent verb is dicere 'to say' (in 10 sentences), and its synonym aio is also quite frequent ( 5 sentences). The other verbs of speech used at least four times are negare 'to deny' (eight times), scribere 'to write' (seven times), and rogare 'to ask' (four times). An exceptional case can be seen in the use of the Greek noun $\kappa \alpha \tau \alpha \kappa \lambda \varepsilon i \varsigma$ 'final remark, conclusion' (1) to introduce indirect speech, which corresponds to the style of the letter as a conversation between learned friends.

(1) Illa tamen $\kappa \alpha \tau \alpha \kappa \lambda \varepsilon i c$ illius est odiosa, quam paene praeterii, si sibi consiliis nostris uti non liceret, usurum quorum posset ad omniaque esse descensurum. (Cic. Att. 9, 18, 3) ${ }^{6}$

If a predicate introduces multiple coordinated clauses, it is counted as one instance.

4 For a description of reported speech including seemingly deviant cases, see, e.g., Bolkestein (1996).

5 For discussion and more details, see Rosén (2013).

6 Latin texts are cited according to Library of Latin texts - Series A (2016) and Library of Latin texts - Series B (2016). 
But I nearly forgot to mention Caesar's disagreeable Parthian shot. If, he said, he could not avail himself on my counsels, he would take those he could get and stop nothing. (transl. by Shackleton-Bailey 1968b: 209)

In two instances, indirect speech follows pronouns because of the ellipsis of the reporting verb. This is particularly evident in (2), where ex me 'he (asked) me' points to the omitted verb quaerere 'to ask', followed regularly by ex +abl. '(to ask) somebody'.

(2) Ille ex me, nihilne audissem novi. (Cic. Att. 2, 12, 2)

Curio asked me whether I had heard the news. (transl. by Shackleton-Bailey 1965: 225, 227)

Ellipsis occurs also in a passage starting with sin praefectus ... vellet esse ... me curaturum 'if he wanted to be a prefect, I would see...' (3), the meaning of which requires a verb such as 'I added', not the negative negavi 'I denied, I told him that ... not'. Omitting the verb of speech within the so-called indirect style is a common practice in Latin, which is possible - in contrast to modern languages - because of the unambiguous marking of indirect speech by the AcI (see Sznajder 2001: 616-617).

(3) Negavi me cuiquam negotianti dare, quod idem tibi ostenderam (Cn. Pompeio petenti probaram institutum meum, quid dicam Torquato de M. Laenio tuo, multis aliis?); sin praefectus vellet esse syngraphae causa, me curaturum ut exigeret. (Cic. Att. 5, 21, 10) I told him that I never gave these appointments to business men, just as I had told you (I explained my rule to $\mathrm{Cn}$. Pompeius when he made a similar request and he approved it, not to mention Torquatus, in the case of your friend M. Laenius, and many others). But I added that if it was because of his bond that he wanted a Prefecture I would see that he got his money. (transl. by Shackleton-Bailey 1968a: 73)

Table 1 (see below) summarizes the formal traits of direct and indirect speech described in the previous paragraphs.

\subsection{Use of indirect speech}

Leaving aside the usual use of indirect speech in narrative parts of the discourse, the use of indirect speech slightly differs from that of direct speech for second-person verbs. Whereas direct speech after these verbs is always hypothetical reaction, remark, or objection, indirect speech is most often used to summarize Atticus' previous letters or opinions. However, there are also instances of indirect speech used for hypothetical objections, reactions, remarks, and exhortations.

\section{Mixed quotations and "voices" outside the domain of reported speech}

As mentioned above, mixed quotations are a type of reported speech in between direct and indirect speech. They are at the same time verbatim citations (i.e. with 


\begin{tabular}{|c|c|c|c|c|c|c|c|c|}
\hline & \multicolumn{4}{|c|}{ Direct speech } & \multicolumn{4}{|c|}{ Indirect speech } \\
\hline & 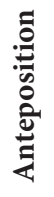 & 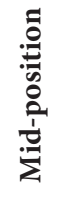 & $\begin{array}{l}\stackrel{0}{0} \\
: \\
0 \\
0 \\
0 \\
0 \\
0 \\
0\end{array}$ & 吾 & 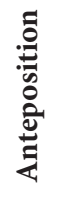 & 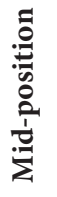 & 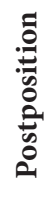 & हैँ \\
\hline Inquam & & 30 & 5 & 35 & & & & \\
\hline Dicere & & & & & 6 & & 4 & 10 \\
\hline Aio & 1 & & & 1 & 4 & & & 5 \\
\hline Respondere & 1 & & & 1 & 1 & & & 1 \\
\hline Negare & & & & & 3 & & 2 & 8 \\
\hline Scribere & & & & & 6 & & 1 & 7 \\
\hline Rogare & & & & & 3 & & 1 & 4 \\
\hline Other verbs or nouns of speech & 1 & & & 1 & 26 & & 7 & 34 \\
\hline Pronouns & 4 & & & 4 & 2 & & & 2 \\
\hline Sic & 1 & & & 1 & & & & \\
\hline Total without zero marking & 8 & 30 & 5 & & 51 & & 15 & 51 \\
\hline Zero marking & & & & 10 & & & & 2 \\
\hline Total & & & & 53 & & & & 73 \\
\hline
\end{tabular}

Table 1. Formal traits of direct and indirect speech

the reported speaker playing a strong role) and are inserted into the sentence syntactically. The examined letters contain eight instances, of which five are citations of Greek authors, one is a citation taken from Ennius, and two are citations of senatus consulta. The most interesting is the citation of Ennius' verse (4). The citation is introduced by inquit, which is specialized in introducing direct speech, but it is integrated into the sentence (ausus es... me rogare, ut... 'you dared ask me to...'), which is clearly not a reported utterance. This unusual sentence structure may have been the reason for the editor to use the brackets and mark inquit Ennius 'Ennius says' as a parenthetical remark.

(4) "Ausus es hoc ex ore tuo" (inquit Ennius), ut equites Scaptio ad pecuniam cogendam darem me rogare? (Cic. Att. 6, 2, 8)

“This hast thou dared from thine own lips", as Ennius says, to ask me to give Scaptius mounted troops to extract the money? (transl. by Shackleton-Bailey 1968a: 111)

The "voices" involved in the letters are not limited to the form of reported speech as defined above or direct communication between the author and the addressee. Typical examples include parenthetical ut clauses that clearly identify the source of 
information as a person alien to the current speaker but within the current speaker's utterance. This form is used for introducing not only a voice alien to the speaker and addressee (5) but also for introducing their proper voices (6).

(5) Cum bona quidem spe, ut ait idem, vel vincendi vel in libertate moriendi iam si pugnandum est, quo tempore, in casu, quo consilio, in temporibus situm est. (Cic. Att. 7, 9, 4)

Then as Pompey says, let us hope for victory, or death with freedom. If we must fight, the time depends on chance, the plan of campaign on circumstances. (transl. by Winstedt 1913: 51)

(6) Quod me ut scribam aliquid hortaris, crescit mihi quidem materies, ut dicis, sed tota

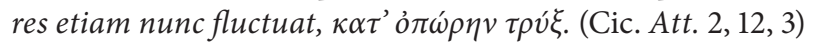

You urge me to write something. My material grows, as you say, but the whole business is still in ferment, must at the vintage. (transl. by Shackleton-Bailey 1965: 227)

Mentioning the addressee can be viewed, together with other devices (e.g. such addressee-oriented pragmatic markers as amabo 'please, be so good'; quaeso 'please'; and age 'come! come on!'; and questions or exhortations to the addressee), as an effort to maintain communication.

Ut clauses make different involved voices explicit, but we are probably not able to identify all of them because of insufficient knowledge of information shared by the speaker and addressee. Voices detectable by a present-day reader include expressions that are or are likely to be proverbs or idioms. One such expression is the $\kappa \alpha \tau$ ' ó $\tilde{\omega} \rho \eta v \tau \rho v ́ \xi$ 'must at the vintage' used in (6).

\subsection{Interaction between different voices}

Cicero's letters to Atticus are exceptional particularly because they mix reported speech, different voices, and different levels of communication. In addition, the transition between these uses can be quick and without strong marking. For this reason, the identity of the speaker can sometimes be inferred only from the context. This mixture is combined with short sentences and thus successfully creates the impression of a currently occurring dialogue. One of the techniques used to achieve this effect is the combination of direct speech, indirect speech, and short narrative descriptions of the situation (7).

(7) Rogat ut eos ad ducenta perducam. "Optime" inquam. Voco illos ad me remoto Scaptio. "Quid vos? Quantum" inquam "debetis?" Respondent "CVI". Refero ad Scaptium. Homo clamare. "Quid opus est" inquam "potius quam rationes conferatis?" Adsidunt, subducunt; ad nummum convenit. (Cic. Att. 5, 21, 12)

So he asked me to bring them up to 20o. "Very good" said I. Then I summoned the Salaminians, Scaptius having left the room. "Well, gentlemen" I said "how much do you owe?" "106 talents" was the answer. I put this to Scaptius. Loud protest. So I said 
"The best thing you can do is to compare accounts". So they set down together and totted everything up. The figures tallied to a penny. (transl. by Shackleton-Bailey 1968a: 75)

Another technique is hypothetical dialogue between the speaker and the addressee. In (8), Atticus' first turn (and, at the same time, the first sentence of the letter) has the form of direct speech introduced by inquis 'you say'. The three following turns do not show any explicit indication of the speaker (quotation marks were added by the modern editor as the result of his interpretation), and so the identities of the interlocutors are inferred from context.

(8) "Cottidie ne" inquis "a te accipiendae litterae sunt?" Si habebo cui dem, cottidie. "At iam ipse ades". Tum igitur cum venero desinam. (Cic. Att. 7, 9)

You may wonder whether you have to expect a letter from me every day. The answer is "yes", provided I have people to take them. And if you point out that I shall be with you in person very soon, I answer that when I am I shall stop writing. (transl. by Shackleton-Bailey 1968a: 131)

Cicero also combines direct speech, addressee-oriented expressions, and his own opinions. In (9), the first utterance is a hypothetical question made by the addressee. The subsequent utterances provide the speaker's answer, but in order to maintain contact with the addressee Cicero uses the pragmatic marker age 'come!'. If this particle were removed, the result would be a regular rhetorical question (used so often in his writings), but contact with the addressee would decrease or disappear.

(9) “Quid si tu velis?” inquis. Age, quis est cui velle non liceat? Sed ego hoc ipsum velle miserius esse duco quam in crucem tolli. Una res est ea miserior, adipisci quod ita volueris. (Cic. Att. 7, 11, 2)

You may say "But supposing you did wish for it?" Come! Anyone is allowed to wish. But I reckon the mere wish a sorrier thing than crucifixion. There is only one thing sorrier still, and that is for a man in such a case to get what he wishes for. (transl. by Shackleton-Bailey 1968b: 134)

\section{Conclusions}

Cicero's letters examined herein show a multi-layered structure of intertwined voices, which is characterized by quick switches between different voices or modes of reporting. The framing level is the conversation-like exchange between the speaker and the addressee into which reported speech, mixed quotations, and other "voices" are inserted. Despite the informal style, direct speech is introduced regularly by the verb inquam, which specialized in introducing direct speech in classical Latin. Even in quite long dialogical passages, it is almost never replaced by synonyms. Although the number of examined letters was small, this finding may be an indication that in Cicero's time, the changes in introducing direct speech which occurred in late 
Latin had not yet begun. For example, there is no sign of increasing use of either aio, partially observable already in Apuleius' Metamorphoses, or other verbs of speech, nor, of course, the participle dicens 'saying', the systematic use of which began much later. The examination of the letters has provided also at least limited insight into the diverse modes of reporting in Latin and points to intermediate types, represented mainly by so-called mixed quotations. Therefore, the results of this examination can add a piece to the picture of the domain of reported, and especially direct speech in classical Latin, which could subsequently be used to examine development over time. Another field open for further research is the manner of inserting citations from authorities into discourse in classical Latin (here inserted in the form of mixed quotations) and possible development into late Latin.

\section{References}

Bolkestein A.M. 1996. Reported speech in Latin. - Janssen T., Wurff W. van der (eds.). Reported speech. Amsterdam: 121-140.

Gayno M. 2015. Les modalités d'insertion du discour direct en latin tardif: bornage et redondance. - Revue de Linguistique Latine du Centre Alfred Ernout De Lingua Latina 10.2. [available at: http://www.paris-sorbonne.fr/IMG/pdf/DLL_11_M-Gayno.pdf].

Library of Latin texts - Series A. 2016. Turnhout. [online database, available at: http://apps. brepolis.net/BrepolisPortal/default.aspx].

Library of Latin texts - Series B. 2016. Turnhout. [online database, available at: http://apps. brepolis.net/BrepolisPortal/default.aspx].

Mikulová J. 2015. Verbs introducing direct speech in Late Latin texts. - Graeco-Latina Brunensia 20.2: 123-143.

Rosén H. 2013. About non-direct discourse: Another look at its parameters in Latin. - Journal of Latin Linguistics 12.2: 231-263.

Shackleton-Bailey D.R. (ed. and transl.). 1965. Cicero's letters to Atticus. [vol. 1]. Cambridge. Shackleton-Bailey D.R. (ed. and transl.). 1968a. Cicero's letters to Atticus. [vol. 3]. Cambridge. Shackleton-Bailey D.R. (ed. and transl.). 1968b. Cicero's letters to Atticus. [vol. 4]. Cambridge. Sznajder L. 2001. Discours indirect et dépendance syntaxique. - Moussy C. (ed.). De lingua Latina novae quaestiones: actes du Xe Colloque International de Linguistique Latine, Paris-Sèvres, 19-23 avril 1999. Louvain: 609-626.

Sznajder L. 2015. Segments introducteurs de discours direct et repérages énonciatifs en latin biblique: éléments pour une étude diastratique et diachronique. - Revue de linguistique Latine du Centre Alfred Ernout De Lingua Latina 10. [available at: http://www.parissorbonne.fr/IMG/pdf/DLL11_SZNAJDER.pdf].

Winstedt E.O. (ed. and transl.). 1913. Cicero. Letters to Atticus. In three volumes. [vol. 2]. London, New York. 